NBER WORKING PAPER SERIES

\title{
CHARTER SCHOOL QUALITY AND PARENTAL DECISION MAKING WITH SCHOOL CHOICE
}

\author{
Eric A. Hanushek \\ John F. Kain \\ Steven G. Rivkin \\ Gregory F. Branch \\ Working Paper 11252 \\ http://www.nber.org/papers/w11252
NATIONAL BUREAU OF ECONOMIC RESEARCH
1050 Massachusetts Avenue
Cambridge, MA 02138
March 2005

The views expressed herein are those of the author(s) and do not necessarily reflect the views of the National Bureau of Economic Research.

(C2005 by Eric A. Hanushek, John F. Kain, Steven G. Rivkin, and Gregory F. Branch. All rights reserved. Short sections of text, not to exceed two paragraphs, may be quoted without explicit permission provided that full credit, including (C) notice, is given to the source. 
Charter School Quality and Parental Decision Making with School Choice

Eric A. Hanushek, John F. Kain, Steven G. Rivkin, and Gregory F. Branch

NBER Working Paper No. 11252

March 2005

JEL No. I2, H4, D1

\begin{abstract}
Charter schools have become a very popular instrument for reforming public schools, because they expand choices, facilitate local innovation, and provide incentives for the regular public schools while remaining under public control. Despite their conceptual appeal, evaluating their performance has been hindered by the selective nature of their student populations. This paper investigates the quality of charter schools in Texas in terms of mathematics and reading achievement and finds that, after an initial start-up period, average school quality in the charter sector is not significantly different from that in regular public schools. Perhaps most important, the parental decision to exit a charter school is much more sensitive to education quality than the decision to exit a regular public school, consistent with the notion that the introduction of charter schools substantially reduces the transactions costs of switching schools. Low income charter school families are, however, less sensitive to school quality than higher income families.
\end{abstract}

Eric A. Hanushek

Hoover Institution

Stanford University

Stanford, CA 94305-6010

and NBER

hanushek@stanford.edu

John F. Kain

School of Social Sciences

University of Texas at Dallas

Richardson, TX 75083
Steven G. Rivkin

Amherst College

Department of Economics

P.O. Box 5000

Amherst, MA 01002-5000

and NBER

sgrivkin@amherst.edu

Gregory F. Branch

Texas Schools Project

University of Texas at Dallas

Richardson, TX 75083

gfb017000@utdallas.edu 


\title{
Charter School Quality and Parental Decision Making with School Choice
}

\author{
by Eric A. Hanushek, John F. Kain, Steven G. Rivkin, and Gregory F. Branch*
}

Charter schools have been championed as the politically feasible form of school choice that offers most of the advantages of voucher schools without sacrificing the benefits of government oversight. The freedom from many of the constraints under which regular public schools operate allows for a diversity of educational approaches and increased competition within the public sector. In just ten years of development, they are found in over three-fourths of the states and their enrollment reaches four percent of the public school population in some states. Nonetheless, even though charter schools have captured the imagination of many school reformers and the ire of others, little credible evidence about their impact on student achievement is available. ${ }^{1}$ This comes about primarily because of the difficulty separating differences in the quality of charter and regular public schools from differences in the students who attend schools in the respective sectors.

This paper uses very rich panel data for the state of Texas to overcome impediments to the evaluation of charter school performance and to investigate the quality of charter schools relative to traditional public schools. Additionally, it provides a first glimpse at how the availability of charter schools affects the ways in which parents respond to school quality differences. By eliminating the need to move residences in order to switch schools, charter

\footnotetext{
* Stanford University, National Bureau of Economic Research, and University of Texas at Dallas; University of Texas at Dallas (deceased); Amherst College and University of Texas at Dallas; and University of Texas at Dallas, respectively. We mourn the loss of John Kain who did not see the completion of this project. Macke Raymond and numerous conference participants provided useful comments. The analysis in this paper has been supported by grants from the Smith Richardson Foundation and the Packard Humanities Institute. We would like to thank Aurora Swanson for excellent research assistance.

${ }^{1}$ Evidence of the intensity of the debate was clear inn late 2004 when a controversy was ignited by the publication of an analysis by the American Federation of Teachers (Nelson, Rosenberg, and Van Meter (2004)) and its wide media coverage. This drew both public and professional reactions (see Hoxby (2004)).
} 
schools would be expected to lead to an increase the sensitivity of parents to school quality and amplify the competitive pressure on public schools.

Although the exact character differs by state, charter schools are hybrids of public and private institutions that allow independent development and decision-making in publicly financed schools that operate under the auspices of some form of public oversight. Charter schools are funded by state and local governments but are exempted from many of the state and local regulations that school reformers have argued stifle innovation and reduce the effectiveness of public schools (Nathan (1996)). To achieve this status, the charter must develop an acceptable educational plan (their charter) and must attract sufficient students to be economically viable. Although appealing as an institutional device to encourage innovation, charter schools are frequently started by people with relatively little experience at either developing new enterprises or running schools. ${ }^{2}$ By any standard, running effective schools is complex. Thus, the public policy issue is how these opposing forces - enthusiasm, freedom, and innovation versus inexperience and complexity - net out in terms of student achievement.

Since the nation's first charter school legislation was enacted into law in Minnesota in 1991, some 41 states and the District of Columbia have enacted legislation that provides for charter schools, although some had yet to open any schools by $2004 .^{3}$ For the nation as a whole, charter schools increased from a handful in 1991 to over 3,000 schools serving an estimated 700,000 students or approximately 1.5 percent of the public school population in 2004 .

Much of the existing research and discussion of charter schools focuses on their growth and characteristics of students enrolling in them (e.g., see U.S. Department of Education (1999), Finn, Manno, and Vanourek (2000)). There is also a small but growing body of evidence on

\footnotetext{
${ }^{2}$ For a description of charter schools including both the legislation surrounding them and the heterogeneity of the sector, see Finn, Manno, and Vanourek (2000).

${ }^{3}$ Current data about charters is fragmentary and must be pieced together from various private sources. See U.S. Charter Schools (http://www.uscharterschools.org); Center for Education Reform (http://www.edreform.com/).
} 
charter school quality as measured by student performance. ${ }^{4}$ Recent work on North Carolina and Florida schools follow the approach used in this paper, but with mixed results. The average North Carolina charter appears less effective than the average traditional public school (Bifulco and Ladd (2004)), while the average Florida charter is on par with the regular public schools after a start-up phase (Sass (2005)). On the other hand, relying upon comparisons between charter applicants in Chicago that were randomly accepted or randomly denied admission, Hoxby and Rockoff (2004) conclude that these charter schools significantly outperformed their regular school counterparts. Texas open enrollment charter schools have been evaluated annually under state contract (see Texas Center for Educational Research (2003)) and by private researchers (Gronberg and Jansen (2001), Booker et al. (2004)). The latter analyses conclude that Texas charters do better than traditional schools, but the analysis depends on a series of analytical adjustments of performance measures.

Our analysis of Texas schools begins by showing that, although charter schools have difficult start-up periods, they settle down within two or three years and are as effective as traditional public schools on average in terms of value added to reading and mathematics achievement. The most novel, and potentially most important aspect of our analysis from a policy perspective, relates to parental decision making. Even though parents undoubtedly have a variety of motivations for choosing individual charter schools, most are likely to be sensitive to the narrow question of quality in basic skills. The results show that the probability of exiting a charter school declines with school quality, although the relationship is weaker for lower income students. The quality responsiveness of families satisfies a necessary condition for the education market to favor higher quality charter schools over time, but the full market dynamics also depend on the character of entry into charters - something that we cannot investigate here.

\footnotetext{
${ }^{4}$ In between the descriptive studies of charter schools and their populations and the evaluations of student performance, Hoxby $(2001$, (2002) examines the impact on charter schools on teacher hiring.
} 
The next section describes the charter school market in Texas. Section III develops the analytical approach used to evaluate charter school performance, focusing on the problems caused by the endogeneity of school choice. The subsequent section presents the findings on average quality differences between charter and regular public schools, which leads into an analysis of how parents react to the heterogeneity of quality. In the following section, we analyze the degree to which exit rates out of charter schools are sensitive to school quality and compare these to quality-exit rate patterns of regular public schools. The final section summarizes the results and policy implications and describes potential extensions for future work.

\section{The Texas Charter School Program}

Texas - the focus of analysis here - is one of the most active charter school states. Since enacting charter school legislation in 1995, the Texas charter sector has grown into one of the largest - ranking fourth among the states in both number of charter schools and number of students in 2004. Because Texas offers a large and diverse set of charter schools, it can provide insights about the potential implications for states that have not been as aggressive in pursuing this reform strategy.

The Texas Education Code established three types of charter schools: home rule school districts, campus or program charters, and open enrollment schools. Open enrollment schools receive their charters directly from the state, while campus and program charters are creatures of individual districts and are chartered by them. The largest number falls under the open enrollment charters governed by the State Board of Education. The Texas legislature placed limits on the number of charter schools that could be operated under the open enrollment program, and this limit has been raised since the introduction of the program in 1995. In 2002, the limit on open-enrollment charters was raised to 215 but a previously uncapped category for schools serving 75 percent or more at-risk students was folded into the total. ${ }^{5}$

\footnotetext{
${ }^{5}$ Charter schools can also have multiple campuses. In 2002, 83 percent operated a single campus but the
} 
Prior to 1997 there were only a handful of charter schools in Texas, but since then the number of charter schools has increased dramatically. Table 1 shows that the percentage of $4^{\text {th }}$ through $7^{\text {th }}$ grade public school students attending charter schools rises from 0.03 percent in 1997 to almost one percent in $2002 .^{6}$ Though still only a small fraction of the entire student body, this growth rate shows both an interest in alternative schools and the consequent supply response. Continued growth at this rate would make charter schools an increasingly important component of Texas public schools.

Participation in charter schools varies substantially by ethnicity and to a lesser extent by family income. As seen in Table 2, blacks have consistently been far more likely to attend charter schools than any other ethnic group. Whites, on the other hand, are much less likely to attend charter schools, although they also have had growth in attendance rates during this period. Interestingly, the differences among ethnic groups are far larger than the differences by family income despite the fact that the initial charter legislation favored schools for disadvantaged populations. (Note, however, that the crude measure of income captured by eligibility for subsidized lunch may conceal important differences by family economic circumstances).

Not surprisingly, the growth in charter school attendance resulted in large part from a rapid increase in the number of charter schools. Table 3 shows that the number of charter schools in their first year of operation rose from less than 20 in 1997 to over 200 in 2001 and 2002. The vast majority of these new schools are chartered by the state, and the number of state charters now dwarfs the number of district charters, a reverse of the situation in the mid 1990s. This change reflects new state legislation that opened up the number of schools that could be chartered. For our purposes, the dramatic growth means that our observations are heavily

remainder had multiple campuses (Texas Center for Educational Research (2003)).

${ }^{6}$ The description of Texas charter schools and the comparisons to regular public schools here relies upon calculations from the UTD Texas Schools Microdata Panel, described below and used in the estimation. Our analytical sample differs from various published charter data because of restrictions on observed student data. 


\section{Table 1. Percentage of Texas Public School Students in Grades 4-7 Attending Charter Schools: 1997-2002}

\begin{tabular}{ccccccc} 
Charter School Attendance & 1997 & 1998 & 1999 & 2000 & 2001 & 2002 \\
\cline { 2 - 7 } Percentage attending charter schools & & & & & & \\
$4^{\text {th }}$ Grade & $<0.01 \%$ & $0.01 \%$ & $0.19 \%$ & $0.42 \%$ & $0.60 \%$ & $0.77 \%$ \\
$5^{\text {th }}$ Grade & $<0.01 \%$ & $0.03 \%$ & $0.21 \%$ & $0.47 \%$ & $0.56 \%$ & $0.79 \%$ \\
$6^{\text {th }}$ Grade & $0.04 \%$ & $0.09 \%$ & $0.35 \%$ & $0.55 \%$ & $0.78 \%$ & $0.92 \%$ \\
$7^{\text {th }}$ Grade & $0.07 \%$ & $0.10 \%$ & $0.31 \%$ & $0.51 \%$ & $0.66 \%$ & $0.91 \%$ \\
\hline All Grades & $0.03 \%$ & $0.6 \%$ & $0.26 \%$ & $0.49 \%$ & $0.65 \%$ & $0.85 \%$ \\
& & & & & & \\
Enrollment in charter schools & & & & & & \\
$4^{\text {th } \text { Grade }}$ & 20 & 33 & 568 & 1,257 & 1,696 & 2,168 \\
$5^{\text {th }}$ Grade & 10 & 81 & 603 & 1,401 & 1,573 & 2,265 \\
$6^{\text {th Grade }}$ & 104 & 268 & 1,027 & 1,671 & 2,245 & 2,711 \\
$7^{\text {th }}$ Grade & 213 & 324 & 922 & 1,559 & 1,937 & 2,697 \\
\hline All Grades & 347 & 706 & 3,120 & 5,888 & 7,451 & 9,841
\end{tabular}

Table 2. Charter School Attendance by Race/Ethnicity and Income in Texas Public Elementary Schools Grades 4-7, 1997-2002

1997

\section{Race/Ethnicity}

Asians

Blacks

Hispanics

Whites

Income $^{\mathbf{a}}$

Low Income

Not Low Income

$\begin{array}{ll}0.02 \% & 0.12 \% \\ 0.06 \% & 0.09 \% \\ 0.04 \% & 0.07 \% \\ 0.01 \% & 0.04 \%\end{array}$

$0.23 \%$

$0.45 \%$

$0.30 \%$

$0.16 \%$

$0.40 \%$

$1.06 \%$

$0.48 \%$

$0.28 \%$

$0.51 \%$

$1.57 \%$

$0.66 \%$

$0.34 \%$

$0.66 \%$

$2.14 \%$

$0.80 \%$

$0.46 \%$

$\begin{array}{llllll}0.03 \% & 0.05 \% & 0.28 \% & 0.52 \% & 0.73 \% & 0.95 \% \\ 0.03 \% & 0.07 \% & 0.25 \% & 0.46 \% & 0.58 \% & 0.74 \%\end{array}$

a. Students eligible for a subsidized lunch are classified as low income. 
Table 3. Distribution of Charter Schools by Chartering Authority and Number of Years in Operation, 1997-2002

\begin{tabular}{cccccc}
1997 & 1998 & 1999 & 2000 & 2001 & 2002 \\
\hline & & & & & \\
17 & 22 & 87 & 168 & 202 & 233 \\
2 & 7 & 10 & 10 & 12 & 15
\end{tabular}

Number of Years in Operation

$\begin{array}{ccccccc}\text { One } & 17 & 10 & 70 & 83 & 43 & 47 \\ \text { Two } & 2 & 16 & 9 & 69 & 78 & 40 \\ \text { Three } & 0 & 2 & 15 & 8 & 68 & 73 \\ \text { Four } & 0 & 1 & 2 & 15 & 8 & 66 \\ \text { Five } & 0 & 0 & 1 & 2 & 14 & 7 \\ \text { Six } & 0 & 0 & 0 & 1 & 2 & 13 \\ \text { Seven } & 0 & 0 & 0 & 0 & 1 & 1 \\ \text { Eight } & 0 & 0 & 0 & 0 & 0 & 1\end{array}$


weighted toward recently opened charter schools. Over 50 percent of our annual observations record performance during the first year two years of school operations.

A substantial decline in average enrollment accompanied the expansion of charter schools, particularly following 1998 (see Appendix Table A1). The median number of students per grade in grades 6 and 7 fell by more than 50 percent, leaving roughly $14-18$ students in each grade.

Charters, like all Texas schools, experience considerable student turnover. Table 4 compares the percentages of students leaving a charter school with those leaving a regular public school (given that the schools had the subsequent grade available). Not surprisingly, exit rates are greater for charters than for the regular public schools, although a portion of this appears to be compositional. The charters have a disproportionate black population, and, independent of the type of school, blacks tend to move much more frequently than other race and ethnic groups (Hanushek, Kain, and Rivkin (2004)). Nonetheless, students attending charter schools show mobility rates substantially above students in regular public schools.

The charter school exit rates show a slight peak in the fifth and sixth grade, suggesting that some transitions might also relate to the structure of the regular public schools and the ability to re-enter at logical points (i.e., middle school transitions). Although we calculate exit rates just for schools that offer the next grade, charter schools still do not in general cover the complete age spectrum - often necessitating a subsequent a return to a traditional public elementary school or a private alternative.

Regardless of ethnicity, however, charter school students are also much more likely to exit Texas public schools than are regular public school students. This summary statistic underscores the necessity of fully accounting for individual differences, because the group that would select charter schools also appears more likely to attend private schools. ${ }^{7}$

\footnotetext{
${ }^{7}$ We do not observe where a student goes following an exit from the Texas public schools. While we can observe mobility across all public schools in the state, including charters, we have no way of tracking
} 


\section{Table 4. Charter and Regular Public School Annual Exit Rates by Destination, Grade, Income and Ethnicity}

(exit rates calculated only for schools that offer the next grade)

$$
\begin{aligned}
& \% \text { charter school students } \\
& \text { exiting to: }
\end{aligned}
$$

\begin{tabular}{|c|c|c|c|c|c|c|}
\hline Destination & Charter & Regular & $\begin{array}{l}\text { Out of Texas } \\
\text { public schools }\end{array}$ & Charter & Regular & $\begin{array}{l}\text { Out of Texas } \\
\text { public schools }\end{array}$ \\
\hline
\end{tabular}

\begin{tabular}{|c|c|}
\hline & $1.9 \%$ \\
\hline
\end{tabular}

\section{Grade}

4th to 5 th grade

$\begin{array}{llclll}2.1 \% & 22.2 \% & 22.8 \% & 0.1 \% & 12.9 \% & 7.2 \% \\ 1.8 \% & 22.4 \% & 19.27 \% & 0.1 \% & 12.5 \% & 6.6 \% \\ 1.9 \% & 19.8 \% & 15.9 \% & 0.1 \% & 10.8 \% & 7.0 \%\end{array}$

6 th to 7 th grade

$1.9 \%$

$1.8 \% \quad 20.8 \%$

$20.1 \%$

$0.2 \%$

$14.7 \%$

$8.4 \%$

Not Disadvantaged

$2.1 \%$

$21.3 \%$

$16.5 \%$

$0.1 \%$

$9.7 \%$

$5.7 \%$

\section{Ethnicity}

Black

$\begin{array}{ll}2.9 \% & 27.4 \% \\ 1.5 \% & 16.8 \% \\ 1.5 \% & 21.2 \%\end{array}$

$22.9 \%$

$0.3 \%$

$17.6 \%$

$8.6 \%$

Hispanic

White

$1.5 \%$

$14.4 \%$

$0.1 \%$

$12.2 \%$

$7.0 \%$

$16.0 \%$

$0.1 \%$

$10.4 \%$

$6.4 \%$ 
This summary view of the evolution of charter schools highlights two features that must enter into the analysis of performance. First, because mobility is high, explicit consideration of the effects of moving is necessary. Our prior work (Hanushek, Kain, and Rivkin (2004)) that investigated mobility in regular public schools found that performance is likely to suffer in the year of the move. ${ }^{8}$ But, more importantly for this analysis, student turnover appears to harm all students in a school regardless of whether or not they themselves move. Charter schools, many of which are start-ups, clearly face challenges of this nature. Second, as highlighted by the pattern of exits out of the Texas public school system, charter school students do not follow the same paths as regular public school students, suggesting that they may differ from regular school students in potentially important ways.

Many questions have also been raised about what choice might do for the composition of schools and particularly the peer groups. Much of the early discussion, perhaps extrapolating from the experiences in elite private schools, suggested that choice would lead to more racial and economic segregation in schools. Past history, however, suggests that private enrollment need not increase overall segregation (e.g., Coleman, Hoffer, and Kilgore (1982); Howell and Peterson (2002)), and charter school effects almost certainly depend on program details.

The charter school experiences in Texas show interesting and diverse patterns of enrollment. Table 5 indicates that the percentage black increases by 14.4 percentage points for black students entering charter schools. In other words, blacks entering charter schools go into more segregated surroundings. At the same time the average black entering a charter school has 10.3 percentage points fewer Hispanic classmates. Hispanics also enter charters with more blacks (0.9 percent) and 5.4 percent fewer Hispanics. For whites, the proportion of both blacks and

movement to private schools or out of the state. We interpret the larger exit rates from Texas public schools as arising from private school attendance, because we see no reason why mobility out of state would be significantly related to attending charter schools.

${ }^{8}$ The exact cause of this achievement loss is difficult to ascertain. Many moves are associated with other family disruptions - divorce, job loss, and the like - and it is not possible to partition the losses between school adjustment factors and nonschool factors; see Hanushek, Kain, and Rivkin (2004). 
Table 5. Change in Racial and Ethnic Composition by Ethnicity and Type of School Transition

\begin{tabular}{|c|c|c|c|c|}
\hline & \multicolumn{2}{|c|}{ Change in Percentage Black when: } & \multicolumn{2}{|c|}{ Change in Percentage Hispanic when: } \\
\hline & $\begin{array}{c}\text { Enters Charter } \\
\text { School }\end{array}$ & $\begin{array}{l}\text { Remains in a } \\
\text { Regular Public }\end{array}$ & $\begin{array}{c}\text { Enters Charter } \\
\text { School }\end{array}$ & $\begin{array}{l}\text { Remains in a } \\
\text { Regular Public }\end{array}$ \\
\hline Blacks & $14.4 \%$ & $-1.5 \%$ & $-10.3 \%$ & $1.0 \%$ \\
\hline Hispanics & $0.9 \%$ & $0.3 \%$ & $-5.4 \%$ & $-0.8 \%$ \\
\hline Whites & $-2.3 \%$ & $0.3 \%$ & $-10.0 \%$ & $0.5 \%$ \\
\hline
\end{tabular}


Hispanics falls upon charter entry (2.3 and 10 percent, respectively). Thus, it appears that Texas charters have led to some additional racial and ethnic concentration, but it does so importantly because of increased choice by black students. Our previous work on racial composition found that higher black enrollment reduced achievement for blacks (Hanushek, Kain, and Rivkin (2002b)), but in this case, where the charters frequently offer specialized programs, it seems entirely possible that the racial composition effects found for regular public schools do not apply.

\section{An Empirical Model of Charter School Effects}

The key estimation issues center on separating charter school effects from simple student selection. We begin with a discussion of related analyses of private school effects, a research line that must address virtually the same methodological issues as those in the study of charter schools, prior to describing the fixed effect approach used in the analysis.

\section{a. Research on Private School Quality}

Starting with the work by Coleman, Hoffer, and Kilgore (1982), the debate over research on public/private school quality differences has centered largely on whether a methodology is able to account for the nonrandom selection of students into private schooling. ${ }^{9}$

One line of research has sought to deal with this problem by modeling the selection process itself. Specifically, if one can obtain a consistent estimate of the probability of attending a private school, it is possible to correct the models of achievement for this in the spirit of Heckman (1979). The typical problem with this approach, however, is that it is difficult to find factors that drive selection into private schools but that are unrelated to achievement, making identification dependent upon tenuous functional form or exclusion restrictions. The validity of any particular approach hinges on the assumptions that the instrument is correlated with the

\footnotetext{
${ }^{9}$ Murnane, Newstead, and Olsen (1985) discuss the difficulties of isolating the impact of private schools on achievement. Studies of the public/private school quality difference include Evans and Schwab (1995); Sander (1996, (2001); Neal (1997); and Grogger and Neal (2000)).
} 
probability of attending private school but otherwise uncorrelated with the outcome of interest, and tests of the latter assumption are generally weak or nonexistent.

A number of recent papers use information on religion as instruments to identify public/private school differences. Yet even if the student's religion (Evans and Schwab (1995)) or the pattern of religion in the area (Neal (1997)) are valid instruments, there is no straightforward generalization to the charter school case.

In a final approach to the statistical correction for selection, Altonji, Elder, and Taber (2005) develop a model where the observed selection effects are proportional to the unobserved selection. This interesting estimation approach, however, rests very heavily upon maintained assumptions about selection that are not readily tested within our context.

An alternate methodology, used first in the analysis of school voucher programs, concentrates on intake randomization. If there is excess demand for a program (say, a privately offered school voucher) and if participants are chosen randomly from those applying, a comparison of those admitted with those not admitted provides information on program performance (e.g., Howell and Peterson (2002)). Such an approach circumvents some of the most serious problems about unobserved influences and student selection on scores. At the same time, these evaluations limit the comparison to those who have selected into the lottery for the program and practical problems with attrition and non-random selection frequently raise some questions about the validity of the experiment.

This intake randomization approach has recently been directly applied to charter schools. Relying on an often observed aspect of state charter laws - that they must choose students by random when there is excess demand, Hoxby and Rockoff (2004) estimate charter school impact by mean differences in performance of those accepted and those denied admission to three schools operated in Chicago by a common charter school authorizer.

Such evaluation opportunities, while providing a plausible basis for estimating program effects, tend to rely on quite specialized experiences and tend to be on a very small scale. Thus, it 
is difficult to know exactly to what circumstances generalizations can be made, and it generally precludes saying anything about program heterogeneity.

The evaluation approach found in the private schooling literature typically compares the average private school to the average public school, ignoring any heterogeneity of either public or private schools. But such treatment heterogeneity is the focus of most research on regular public schools. ${ }^{10}$ We return to treatment heterogeneity below in the context of parental choice.

\section{b. Panel Based Estimators of Mean Differences}

Rather than attempting to adjust outcome comparisons among different students, we deal with the selection problems by concentrating on outcome differences for students moving between regular public schools and charter schools. This panel data approach immediately removes the most obvious sources of bias caused by unobserved heterogeneity, although some concerns remain.

As an overarching framework, we view the schooling process as cumulative in the sense that achievement depends upon the entire past history of family, community, and school inputs including mobility. The data requirements to model the entire achievement process are generally prohibitive. Consider, however, a value-added model of achievement growth in which annual learning gains $(\Delta \mathrm{A})$ for student $\mathrm{i}$ in school $\mathrm{s}$ in year $\mathrm{t}$ is a function of individual and family factors and type of public school. To the extent that historical factors are captured by prior achievement, such a formulation permits concentration on just contemporaneous circumstances. ${ }^{11}$

$$
\begin{aligned}
\Delta A_{i s t} & =A_{i s t}-A_{i, s-1, t-1} \\
& =\beta C H_{s t}+m_{i s t} \lambda+\gamma_{i}+\delta_{i t}+\varepsilon_{i s t}
\end{aligned}
$$

\footnotetext{
${ }^{10}$ In a refinement of the basic approach, Neal (1997) considers how private school choice varies by geography (central cities and suburban areas), but the comparisons still disregard significant differences among schools with more tightly defined markets.

${ }^{11}$ Since the level of achievement at any point will be related to cumulative family and school inputs to the time, value-added models can circumvent many problems of omitted or mismeasured past inputs. See Rivkin, Hanushek, and Kain (2005) for the development of a comprehensive model of education production. While various alternative specifications have been employed, preliminary work showed that coefficients on variables of interest were not sensitive to the precise form of the value added model.
} 
where $\mathrm{CH}_{\text {st }}$ is a dummy variable indicating that school $\mathrm{s}$ is a charter school, $\mathrm{m}_{\text {ist }}$ is a dummy variable indicating a school transfer in year $t, \gamma$ captures all fixed family and individual influences on achievement, $\delta_{\text {it }}$ captures systematic influences that vary over time for student $\mathrm{i}$, and $\varepsilon$ is an idiosyncratic error.

Cross-sectional estimation of this gains model would generate an estimate of $\beta$ based on the difference in achievement gains between students attending charter schools and those attending regular schools, controlling for any observable differences in family and community background. Such an approach likely leads to biased estimates of the benefits of charter schools, because the probability of attending a charter school is almost certainly correlated with unobserved differences among students (i.e., $\operatorname{cov}(\mathrm{CH}, \gamma+\delta+\varepsilon) \neq 0$ ). This is precisely the problem that has impeded the estimation of the private school premium. ${ }^{12}$

Our approach employs panel data with multiple observations of gains for each student, enabling students to serve as their own controls. By introducing student fixed effects in achievement growth $(\gamma)$, our estimates of the benefit of charter schools come from the difference between achievement gain while attending a charter school versus achievement gain while attending a regular public school.

The use of transitions to identify the charter school effects, although having many advantages, also raises a number of concerns that need to be addressed. First, the decision to switch into a charter school might result from a negative school quality shock in the regular public schools such as placement in a classroom with an ineffective teacher or disruptive group of peers. In this case the gains of those who subsequently transition to a charter would be systematically lower than the average for the regular public school, leading to an upward biased estimate of the average quality differential between the charter and regular public schools attended by these students.

\footnotetext{
${ }^{12}$ In reality, the majority of studies of private schools have looked at the level of achievement, making the problems of omitted variables much more severe and unquestionably increasing the bias.
} 
Second, a negative shock to the family might temporarily reduce performance and prompt a switch to a charter school. Both phenomena are very similar to the evaluation problem when there is a preprogram dip in earnings prior to entering job training. ${ }^{13}$ Fortunately, the availability of multiple years of data permits us to directly investigate the existence of such temporary declines through the use of interrupted panel estimators that exclude the year prior to the move from the analysis. ${ }^{14}$ We can also compute separate estimates for those who transition from regular to charter schools and those who transition from charter to regular schools.

A third concern is the direct effect of mobility on academic achievement (see Hanushek, Kain, and Rivkin (2004)). Again, the panel data permit us to control directly for any systematic move related transactions cost through the inclusion of an indicator variable for a school transfer.

A fourth issue is whether the TAAS examination used by the State of Texas can provide a meaningful estimate of school quality differences given the non-random selection of students among schools. Because the test focuses on basic skills, differences in instructional quality likely translate into very different rates of improvement in measured test score gains across the initial achievement distribution. For example, the difference in test scores generated by a substantial improvement in the quality of instruction may be quite sizeable for a student who begins at the lower end of the skill distribution and for whom the test covers much of the knowledge gained by virtue of higher school quality. On the other hand, it may be that a student higher up the initial skill distribution would answer most of the questions correctly, even if taught in quite a low quality school. That is, better instructional quality may translate into only a few additional correct answers if the test does not concentrate on or cover the additional knowledge generated for high performing students by the better instruction.

\footnotetext{
${ }^{13}$ Heckman and Smith (1999) discuss the implications of a preprogram decline for the estimation of job training program effects.

${ }^{14}$ In our related work using similar methods, analysis of special education program effects failed to find any evidence of temporary dips or improvements prior to program entry (see Hanushek, Kain, and Rivkin (2002a).
} 
In the context of equation 1 , this problem suggests that measured school quality is a function of the initial distribution of student achievement, and that the difference in test score gains produced by two schools may depend critically on this distribution. Importantly, because student fixed effects identify charter school effects on the basis of changes in achievement gain following a transition, their inclusion mitigates this problem by comparing a student with herself. Nevertheless, both to reduce further the possibility that sector differences in student academic preparation across schools influence the results and to learn more about the sources of differences of estimated charter school effects from fixed effects and from regression based estimates employing just measured factors, we generate a standardized gain for each student. This standardized gain is based on comparisons between a student's nominal gain and the average gain in achievement for all students in Texas at the same initial achievement level.

First, we divide the initial test score distribution into twenty equal intervals $\left(\mathrm{c}_{\mathrm{m}}\right.$ for $\mathrm{m}=1, \ldots, 20)$ and for each year compute the mean and standard deviation of the gains for all students starting in that interval. Specifically, suppressing the notation for year and school, for all students with $\mathrm{A}_{\mathrm{it}-1}$ in the interval $\mathrm{c}_{\mathrm{m}}$ defined by $\left[A_{t-1}^{c_{m}}, \widehat{A}_{t-1}^{c_{m}}\right]$ for a given year,

$$
\begin{gathered}
\mu_{t}^{c_{m}}=\left(\overline{A_{i t}-A_{i t-1}}\right), \text { and } \\
\sigma_{t}^{c_{m}}=\sqrt{\sum\left(\left(A_{i t}-A_{i t-1}\right)-\mu_{t}^{c_{m}}\right)^{2} / n_{c_{m}}}
\end{gathered}
$$

The standardized gain score for each student in the interval $\mathrm{c}_{\mathrm{m}}$ is then calculated as:

$$
\Delta A_{i s t}=\left[\left(A_{\text {ist }}-A_{\text {ist-1 }}\right)-\mu_{t}^{c_{m}}\right] / \sigma_{t}^{c_{m}}
$$

Consequently, gains in each interval are distributed with a mean of zero and a standard deviation of one in each year.

A fifth concern not addressed here is that the presence of a charter school in the community provides an incentive for regular schools to raise the quality of instruction. Given that Texas already had a school reward program linked to the TAAS test in place, it may be unlikely 
that the entry of a new charter school has a large additional impact on regular school performance. Nonetheless, the possibility that regular schools responded and raised achievement gains thereby biasing downward the estimated charter school effect should be considered. ${ }^{15}$

A final issue concerns the generalizability of the results. Because the charter school effect is identified from the change in achievement gains for those who enter or exit charter schools, it is an open question as to the extent that these estimates are relevant for the student body as a whole. The general issue frequently arises in program evaluations; see Heckman, LaLonde, and Smith (1999). If those who expect to receive higher benefits from attending a charter school are more likely to enroll (perhaps because they attend lower quality public schools), the estimated benefit may overstate the expected gain to the average student, even though it provides a consistent estimate of the benefit of charters for those who attend. This is also complicated in the charter school case because state testing begins in grade 3, meaning that earlier entry into charters is not observed and may be different.

In addition, estimates of sector average differences during the 1990s almost certainly provide inaccurate information on likely differences in the coming years for two important reasons. First, because the legislation creating the charter school program was only recently implemented, most charter schools have been in existence for only a short period of time. If it takes schools a year or two to get up to speed, estimates of the average benefits of charter schools for the period under study will not capture the long term or steady state differences between the two sectors. Consequently we divide charter schools into groups based on years in existence and examine average differences in charter school effectiveness by age. Second, the stock of charter schools at any point in time is determined by the pattern of school openings and closings in prior years. One of the main assumptions underlying support for school choice is that information on

\footnotetext{
${ }^{15}$ Hoxby (2003) suggests that charters and vouchers in other states have spurred the public schools to perform better, although the competitive effects are less clear in Arizona, a rapidly growing state like Texas. On the other hand, Texas Center for Educational Research and others (2001) suggests from survey information that there is limited reaction of the public schools to the existence of a charter.
} 
school quality is available and that parents act on that information by gravitating toward effective schools and away from ineffective schools, leading to quality based closings.

\section{The UTD Texas Schools Microdata Panel}

The cornerstone of this research is the analysis of a unique microdata set of school operations constructed by the Texas Schools Project at the University of Texas at Dallas. ${ }^{16}$ The database tracks students as they progress through school; it measures student performance each spring; and it contains detailed information about schools and teachers. This analysis follows four consecutive cohorts for the period 1996 to 2002, focusing on student achievement gains in grades 4 through 7. For each cohort there are more than 200,000 students in over 3,000 public schools eventually including over 200 charter schools. The large numbers of students who enter and exit charter schools are especially important for the methodology pursued here.

Beginning in 1993, the Texas Assessment of Academic Skills (TAAS) was administered each spring to eligible students enrolled in grades three through eight. Unique IDs link the student records with the test data. The criteria referenced tests evaluate student mastery of grade-specific subject matter and provide the basis for our measure of student outcomes. We use mathematics and reading test scores in this paper. Because the number of questions and average percent right vary across time and grades, we begin by transforming all test results into standardized scores with a mean of zero and variance equal to one. Preliminary results for mathematics and reading were quite similar, leading us to concentrate on a composite score constructed by averaging the standardized math and reading scores for each student in each year and re-standardizing to yield a single achievement measure as a $\mathrm{z}$-score. ${ }^{17}$ The adjusted gain measure derived in equation 4 is calculated using this composite score.

\footnotetext{
${ }^{16}$ A more detailed description of the underlying database can be found in John F. Kain, "Description of the UTD Texas Schools Project" (2001), and other publications on the website for the UTD Texas Schools Project (http://www.utdallas.edu/research/tsp/).

${ }^{17}$ The composite score $A_{i s t}=\left[\left(A_{i s t}^{M}+A_{i s t}^{R}\right)-2 \mu_{t}^{A}\right] / 2 \sigma_{t}^{A}$ where $\mu_{t}^{A}=\overline{\left(A_{i s t}^{M}+A_{i s t}^{R}\right) / 2}$,
} 
The data contain a limited number of student, family and program characteristics including race, ethnicity, gender and eligibility for a free or reduced price lunch. Nonetheless, the panel feature can be exploited to account implicitly for time invariant individual effects on achievement. Importantly, students who switch schools can be followed as long as they remain in a Texas public school.

The TAAS data are merged with information on whether a school is a state authorized charter, a district authorized charter, or a regular public school. Any school without any students in the TAAS data set is excluded from the sample, therefore our number of charters will differ from public records of the number of authorized charter schools. (Note that students do not have to have to complete the tests to be included in the TAAS file). Also omitted are those charter schools exclusively serving children with special needs, as well as those serving the residents in treatment programs or disciplinary facilities.

School transitions $\left(\mathrm{m}_{\mathrm{it}}\right)$ are constructed to exclude those that result from the structure of school districts. In other words, the transitions from elementary to middle or junior high schools are not considered moves, and a separate dummy variable captures the effect of such transitions.

\section{Average Effects of Charter Schools on Achievement}

Initial estimates of overall charter school effects on combined mathematics and reading achievement come from a series of specifications based upon equation (1). For each specification, charter school effects are presented for all charters (top panel) and by years in operation (bottom panel). All specifications include indicators for subsidized school lunch eligibility and year-by-grade (to allow for differences in tests across years). Specifications that do not remove student fixed effects also include a vector of ethnic dummy variables (Asian, black, Hispanic and Native American) and a dummy for gender. Standard errors are adjusted for

$\sigma_{t}^{A}=\sqrt{\sum\left(\left(A_{i s t}^{M}+A_{i s t}^{R}\right)-\mu_{t}^{A}\right) / n_{t}}, A_{i s t}^{M}$ is the student's math score at school s in year t standardized with respect to the statewide distribution, and $A_{\text {ist }}^{R}$ is the analogous metric for reading. 
the clustering of students into schools. Following discussion of the basic results, we report a series of specification checks.

\section{a. Basic Results}

The simple analysis of the level of achievement, found in the first column of Table 6 , provides a convenient benchmark that can be readily compared to some of the early analyses of performance, including those using the National Assessment of Educational Progress (Nelson, Rosenberg, and Van Meter (2004)). The estimated difference in scores combines both the immediate effect of the charter and the entire past history of family and school differences. It shows that charters on average tend to attract a sample of students with systematically lower levels of achievement than do regular public schools. However, the estimates for all charter schools combined conceal differences by number of years in operation. The difference is greatest for schools in their first year of operation (0.39 standard deviations) and decreases with operational experience, becoming insignificant after three years of school operation.

The remaining columns report results from a series of value added specifications that successively add student fixed effects and controls for mobility, peer turnover, and peer average initial achievement. Using a value added, or gain, specification rather than a levels specification reduces the magnitude of the charter school coefficient by roughly 0.06 , but the additional inclusion of student fixed effects increases the effect size above that of the simple levels model. This indicates that compositional differences across sectors tend to attenuate estimates of the average charter school deficit in Texas.

Although controls for student mobility have little effect on the charter school coefficient, the inclusion of the peer turnover variable reduces its magnitude by more than 50 percent. This is consistent with the much higher share of new students in charter schools and the negative impact of student turnover found in earlier work on Texas (Hanushek, Kain, and Rivkin (2004)). It is nonetheless premature to attribute such an important role to turnover, because turnover is by definition much higher in new schools in which none of the students are non-movers; thus, as 
Table 6. Estimated Effects of Charter Schools on 4th-7th Grade Combined Test Score Levels and Gains (absolute value of Huber-White adjusted $t$ statistics in parentheses; $n=3,293,340$ )

\begin{tabular}{cccccc}
\hline Levels $\left(\mathrm{A}_{\mathrm{i}}\right)$ & \multicolumn{5}{c|}{ Achievement Gains $\left(\Delta \mathrm{A}_{\mathrm{i}}\right)$} \\
NO & NO & YES & YES & YES & YES \\
NO & NO & NO & YES & YES & YES \\
NO & NO & NO & NO & YES & YES \\
NO & NO & NO & NO & NO & YES \\
& & & & & \\
$-0.24^{* *}$ & $-0.18^{* *}$ & $-0.29^{* *}$ & $-0.28^{* *}$ & $-0.13^{* *}$ & $-0.17^{* *}$ \\
$(2.73)$ & $(3.00)$ & $(6.08)$ & $(5.99)$ & $(2.8)$ & $(2.85)$ \\
& & & & & \\
\end{tabular}

Charter School by Years in Operation

Student fixed effects

Own mobility

Peer turnover

Peer Past Achievement

Charter School

$-0.39 * *$

One

$$
\text { (3.57) }
$$

$-.053 * *$

$-0.64 * *$

$-.058 * *$

$-0.33^{* *}$

$-0.33 * *$

Two

(4.54)

(5.72)

(5.34)

(2.97)

(2.92)

Two

$-0.26^{* *}$
$(2.99)$

$-0.20 * *$

$-0.33 * *$

$-0.33 * *$

$-0.19^{* *}$

$-0.25^{* *}$

(2.99)

(3.13)

(5.43)

(5.32)

(3.05)

(3.48)

Three

$\begin{array}{cc}-0.27 * * & -0.08 \\ (2.89) & (1.03)\end{array}$

$-0.09$

$-0.11$

0.01

$-0.08$

Four

$\begin{array}{ll}-0.1 & -0.01 \\ (-0.79) & (0.11)\end{array}$

(1.15)

(1.44)

(0.15)

(1.06)

$$
(-0.79)
$$

$-0.06$

$-0.09$

$-0.001$

0.00

Five or more

$$
\begin{gathered}
0.09 \\
(0.64) \\
* *=1 \%
\end{gathered}
$$

0.13

(0.84)

(1.3)

(0.01)

$(0.01)$

Significance: $\sim=10 \%$

(1.51)

0.07

0.03

0.084

(0.63)

0.06

$\begin{array}{lll}(0.26) & (0.63) & (0.68)\end{array}$

Note: All models include: Economic status and year by grade dummies, and models without student fixed effects also include gender and ethnicity dummies; own mobility is an indicator of whether the student moved in the given year; peer turnover is the percentage of students who left in each year. Peer achievement is the initial achievement level of the other students in the same grade and school. 
discussed below, the turnover coefficient may also capture problems endemic to new schools.

Finally, the addition of peer initial achievement slightly increases the magnitude of the charter school coefficient, indicating that the initial achievement differential between traditional public and charter schools is not one of the net contributors to the poorer average performance in charter schools. ${ }^{18}$

To investigate the linkage between charter school quality and years of operation, specifications reported in the lower panel of Table 6 replace the single charter school treatment variable with a series of dummy variables indicating the age of the charter school. The results show that the inferior performance of charter schools is concentrated among schools in their first and second years. In no specifications do older charter schools perform systematically worse than traditional public schools. In addition, the inclusion of the turnover variables has the largest effect on the first and second year charter school coefficients, not surprising given that a much higher share of students are new entrants in these schools.

We also explored the possibility of systematic differences by student demographic characteristics including family income and race. If lower income and minority students attend lower quality public schools, one might expect these students to enjoy larger benefits from charter school attendance. The results (not reported), do not reveal such systematic differences. ${ }^{19}$

\section{b. Sensitivity Analysis}

The charter school effects in the fixed effects specifications are identified by the difference in achievement gains in a charter and in a traditional public school, implying that the estimates will be biased if there are unmeasured changes in personal well-being or the family environment (captured in $\delta_{i t}$ in Equation 1) that are systematically related to the decision to enter or exit a charter school. For example, a temporary downturn in a student's academic performance

\footnotetext{
${ }^{18}$ As noted in a variety of places, estimation of peer effects is difficult because of both omitted variables problems and possible simultaneity (see the discussion in Hanushek, Kain, and Rivkin (2002b)). Here we employ lagged peer characteristics to capture "characteristics" as opposed to current behavior.

${ }^{19}$ These findings differ from those of Gronberg and Jansen (2001), who find larger benefits for disadvantaged students but using very different empirical specifications.
} 
that triggers entry into a charter but that is subsequently reversed will bias estimated charter school quality upward because it induces a positive covariance between the charter treatment and the error. In essence, the estimates of the charter school coefficient confound the actual charter school effect with the recovery from the negative shock, similar to the phenomenon described as Ashenfelter's dip in the job training literature (Heckman and Smith 1999).

Even in the absence of any such changes, the decision to transfer depends on both the quality of the specific charter or traditional school and the match quality of the student with the school. This is particularly important in the case of students exiting charter schools who are likely to have attended lower quality charters than the average student. ${ }^{20}$

We examine a series of additional specifications to understand the magnitude of these potential biases. First, we separate transitions into charter schools from transitions out of charter schools, generating two different estimates of the charter/traditional public school differential. Second, to consider any biases introduced by temporary falls in achievement, we compute interrupted panel estimates of charter school quality. Consider a student who faces a temporary downturn in grade 6 and transfers to a charter school in grade 7. Because the grade 6 test score is both the post-test score in calculating the grade 6 achievement gain and the pretest score in calculating the grade 7 gain, the temporary downturn would deflate achievement growth while not in a charter and inflate it while in a charter, both of which bias upward estimates of charter school quality. If, however, information on gains in the year prior to entering a charter (grade 6) were not considered and the estimates were computed from comparisons of gains in just grades 7 and 5, any upward bias should be much smaller, because the transitory dip during grade 6 is removed from the pre-program comparison (even though it still inflates the gain in grade 7).

Table 7 reports separate charter school coefficients for entrants and exits. The much more negative charter school coefficient for exits in Table 7 fits with the notion that those who

\footnotetext{
${ }^{20}$ These issues and sensitivity analyses are similar to those described in Hanushek, Kain, and Rivkin (2002a) in the context of special education.
} 
Table 7. Separate Estimates of Charter School Effects for Entrants into and Exits from Charter Schools

(absolute value of Huber-White adjusted t statistics in parentheses)

\begin{tabular}{ccc} 
& \multicolumn{2}{c}{ Achievement Gains $\left(\Delta \mathrm{A}_{\mathrm{i}}\right)$} \\
& Entrants & Exits \\
Charter School & $-0.18^{* *}$ & $-0.90^{* *}$ \\
& $(4.21)$ & $(11.57)$ \\
Charter School by Years in Operation & \\
One & $-0.48^{* *}$ & $-1.35^{* *}$ \\
& $(4.49)$ & $(12.1)$ \\
Two & $-0.24 *$ & $-0.81^{* *}$ \\
& $(3.99)$ & $(7.54)$ \\
Three & -0.01 & $-0.39^{* *}$ \\
& $(0.14)$ & $(2.88)$ \\
Four & -0.02 & $-0.41 * *$ \\
& $(0.2)$ & $(2.7)$ \\
Five or more & 0.10 & -0.07 \\
& $(0.9)$ & $(0.23)$ \\
Observations & $3,291,830$ & $3,287,941$ \\
& $* *=1 \%$ &
\end{tabular}

Note: All models include economic status, year-by-grade dummies, and student fixed effects. 
exit charter schools have had a far worse experience in the charter school than the typical charter school student. Even students who exit older charter schools fare significantly better upon returning to a traditional public school. These results suggest that school-student match may be quite important (and nonuniform across students). It could also be explained by within school variation in teacher quality (Hanushek et al. (2005)) that led to exits.

Finally, the pattern of estimates in Table 8, relying on the interrupted panel estimates for entrants, provides little support for the view that many entrants to charter schools experience temporary negative shocks that precipitate the switch. The similarity of results from estimation with all switches and estimation excluding the year of switching is striking. Therefore it does not appear that the charter school coefficients conflate the true charter school effect with recovery from a temporary negative shock.

\section{Heterogeneity and Parental Decision Making}

The conceptual arguments undergirding charter school reform efforts are directly adapted from the original arguments of Milton Friedman for support of voucher schools (Friedman (1962)). Developing competitive markets for schooling would offer alternative types of schools that better meet consumer desires, would foster innovation and the introduction of alternative pedagogies and curriculum, and would lead to more efficient supply through competition of schools for students. But, while picking up the conceptual arguments for more choice, charter schools also pick up the arguments against. ${ }^{21}$ One persistent assertion is that parents, and particularly low-income parents, are likely to be poor consumers of quality - perhaps because of informational problems, lack of attention, lack of experience, or the complexity of the problem given the time until the results can be fully observed. To investigate the responsiveness of parents to school quality, we analyze the effects of school quality on the decision to exit a school

\footnotetext{
${ }^{21}$ Charter schools avoid the argument that the competitive schools would only seek profits and would not serve society's interests. An appeal of charter schools is that they are fully under public control and thus would not be permitted to pursue programs outside of society's interest.
} 
Table 8. Interrupted Panel Estimates of Charter School Effects for Entrants into Charter Schools

(absolute value of Huber-White adjusted t statistics in parentheses)

\begin{tabular}{ccc}
\hline All Entrant & Before \& After & Omit Before Switch \\
observations & Only &
\end{tabular}

Charter School

$-0.187 * * \quad-0.025 * *$

$(4.72)$

$-0.192 * *$

(3.62)

\begin{tabular}{|c|c|c|c|}
\hline \multicolumn{4}{|c|}{ Charter School by Years in Operation } \\
\hline One & $\begin{array}{c}-0.427^{* *} \\
(3.98)\end{array}$ & $\begin{array}{c}-0.463 * * \\
(3.97)\end{array}$ & $\begin{array}{c}-0.461 * * \\
(4.52)\end{array}$ \\
\hline Two & $\begin{array}{c}-0.263 * * \\
(3.85)\end{array}$ & $\begin{array}{c}-0.297 * * \\
(4.31)\end{array}$ & $\begin{array}{c}-0.27 * * \\
(4.17)\end{array}$ \\
\hline Three & $\begin{array}{l}-0.028 \\
(0.34)\end{array}$ & $\begin{array}{l}-0.06 \\
(0.68)\end{array}$ & $\begin{array}{l}-0.003 \\
(0.03)\end{array}$ \\
\hline Four & $\begin{array}{c}-0.039 \\
(0.46)\end{array}$ & $\begin{array}{c}-0.16 \\
(1.48)\end{array}$ & $\begin{array}{c}-0.013 \\
(0.16)\end{array}$ \\
\hline Five or more & $\begin{array}{l}0.045 \\
(0.36)\end{array}$ & $\begin{array}{c}0.08 \\
(0.58)\end{array}$ & $\begin{array}{l}-0.015 \\
(0.12)\end{array}$ \\
\hline $\begin{array}{c}\text { Observations } \\
\text { Sionificance } \sim=10^{\circ}\end{array}$ & $\begin{array}{c}3,288,448 \\
*-50 \\
* *-10\end{array}$ & $3,284,291$ & $3,285,922$ \\
\hline
\end{tabular}

Note: All models include economic status, year-by-grade dummies, and student fixed effects. 


\section{a. Analytical Focus}

The charter schools that have developed follow a wide variety of principles and conceptual models, including simply "doing better" than the regular public schools, providing alternative curricular and pedagogical focus, emphasizing discipline or moral values, developing the arts, and the like (Texas Center for Educational Research (2003)). These alternatives may not map simply into measured student achievement, and, as such, consumers with different preferences may well be accurately making optimal choices - even if they do not reflect quality in terms of math and reading performance.

Nevertheless, in designing their testing system the State of Texas has made higher achievement a primary objective of public education. Thus, we evaluate the narrow question of whether consumers respond to academic quality. This focus is also important because competition in this dimension could more directly influence the quality of instruction in the overall school market through forcing lower quality schools to either reform or exit the market. Given that most charter schools are quite new, we are unable to examine the longer term dynamics of the market. In addition, we can currently provide only limited information on the determinants of the decision to enter a charter and no information about the decision to open a charter, even though both are important aspects of market dynamics. Here we focus on the responsiveness of families to quality in terms of the decision to exit the current school.

It is natural to believe that some charters are much better than others in raising the achievement of children, just as we observe substantial variation within the regular public school sector. The consumer problem is not trivial, however, because consumers lack direct information on school quality. The state accountability system produces information on the level of student performance but not on the value added of the school or even on the gains of students in the school. Parents must supplement the limited performance information with first-hand knowledge of school operations that may or may not be strongly related to actual school effectiveness at raising achievement. 
We develop an outcome based school quality measure equal to the residual of a regression of school average achievement gain in a given year on a number of student demographic characteristics. In order to account fully for school differences in the distribution of initial achievement, the school average gain measure weights students in each achievement interval by the state-wide share of students in that interval (instead of the specific distribution in each school):

$$
\overline{\Delta A}_{s t}^{w_{C}}=\sum_{m=1}^{20}\left(\overline{\Delta A}_{c_{m} s t} W_{c_{m}}\right)
$$

where $\overline{\Delta A}_{c_{m} s t}$ is the average standardized achievement gain for group $\mathrm{m}$ at school $\mathrm{s}$ in year $\mathrm{t}$ (from equation 4), and $w_{c_{m}}$ is the statewide share of students for interval $\mathrm{m}$. This fixed weight measure goes one step further than previously to ensure that the school performance is not biased by the particular selection of students in each school. ${ }^{22}$ This aggregate school performance is then regression adjusted for demographic and gender composition, proportion of disadvantaged and migrant students, grade distribution in the school, and the proportion of new students. Our school quality measure, which varies by school and year, is the residual:

$$
\hat{v}_{s t}=\overline{\Delta A}_{s t}^{w_{C}}-p_{s t} \hat{\kappa}
$$

where $p_{s t}$ is the vector of student body composition and school structure variables and $\hat{\kappa}$ are the estimated OLS parameters.

Kernel density plots of $\hat{v}$ in Figure 1 reveal considerable heterogeneity in the effectiveness of charter and traditional public schools. Of course a portion of the variation reflects sampling error, and the much larger variation in the charter sector results at least in part from the much smaller enrollment levels in most charter schools. Nevertheless, the systematic

\footnotetext{
${ }^{22}$ It would, however, go too far if some schools in fact developed specialized programs that were complementary to specific groups of students (in terms of entering performance). Investigations of individual teacher differences in Texas data for one central city, however, did not indicate strong specialization with students (Hanushek et al. (2005)).
} 
Figure 1: Kernal Density Estimates of the Distribution of the Regression Adjusted School Quality Measure for Charter and Regular Public Schools

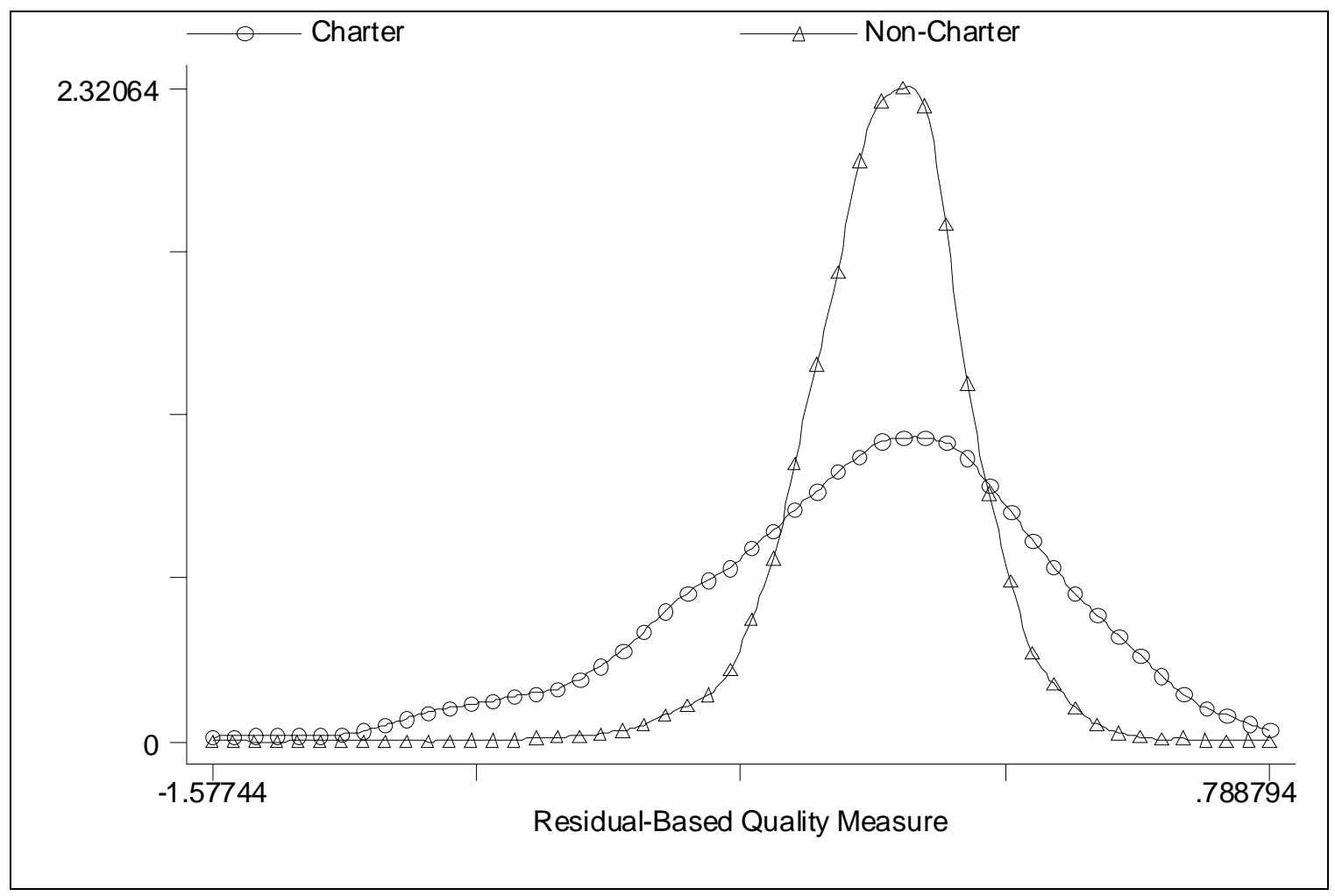


quality differences by years of operation capture real performance differences, and there can be little doubt given existing evidence on the variation in teacher and school quality that there are substantial quality differences even for charters of the same age. ${ }^{23}$

\section{b. Parental Decisions}

Are school exit decisions affected by the quality of instruction? And is the sensitivity to school quality greater in the charter school sector? To answer these questions, we estimate a series of linear probability models in which the probability of exiting is regressed on school average standardized gain (equation 6) in charter schools and regular public schools. ${ }^{24}$ All models include a vector of dummy variables for student ethnicity, migrant status, school mobility, gender, and family income, and indicator variables for individual years of school operation (which are all equal to zero for traditional public schools). ${ }^{25}$ The addition of peer turnover and other school composition variables provides information on the extent to which peer factors appear to enter independent of school quality. We also include a student's own academic gain in some specifications, because factors specific to an individual student's performance may also be related to the probability of moving. ${ }^{26}$

Table 9 presents estimates of the effects of school quality on the probability of exit. In contrast to the very small and mostly insignificant effect of quality on the probability of exiting regular public schools, school quality has a negative and highly significant effect on the probability of exiting charter schools in all specifications. ${ }^{27}$ Importantly, the virtual invariance of the point estimates to the inclusion of peer turnover or peer initial achievement suggests that

\footnotetext{
${ }^{23}$ See Rivkin, Hanushek, and Kain (2005) and Hanushek et al. (2005) for evidence on variation in the quality of instruction both within and between schools.

${ }^{24}$ For this estimation, the precision of the school quality estimates is ignored, and no adjustments are made to the standard errors because of the inclusion of estimated residuals as regressors. Logit models produce an identical pattern of results.

${ }^{25}$ Given the growth in the school population over the period, new regular public schools do open in our sample. Nonetheless, the appropriate school age for regular public schools seems much more associated with having an on-going administrative structure, curriculum, and so forth than just building age.

${ }^{26}$ Hanushek et al. (2005) find considerable within school variation in teacher quality, explaining how individual student performance could systematically differ from the expectation for the whole school. 27 The hypothesis that the effect of quality on the probability of exit equals zero is rejected at the one percent level in all specifications.
} 
Table 9. Estimated Effects of School Quality on the Probabilities of Exiting Charter and Regular Public Schools

(absolute value of $\mathrm{t}$-statistics in parentheses; $\mathrm{n}=1,349,909$ )

\begin{tabular}{lcccc}
\cline { 2 - 5 } & $\mathbf{( 1 )}$ & $\mathbf{( 2 )}$ & $\mathbf{( 3 )}$ & $\mathbf{( 4 )}$ \\
Student Characteristics & YES & YES & YES & YES \\
School/Peer Characteristics & NO & YES & YES & YES \\
Peer Achievement & NO & NO & YES & YES \\
\hline & & & & \\
Linear Probability Model & -0.002 & 0.006 & 0.006 & $0.015^{* *}$ \\
Quality & $(0.47)$ & $(1.42)$ & $(1.4)$ & $(3.66)$ \\
& $-0.152^{* *}$ & $-0.142^{* *}$ & $-0.138^{* *}$ & $-0.126^{* *}$ \\
Quality X Charter & $(4.57)$ & $(4.23)$ & $(4.12)$ & $(3.72)$ \\
& & & & $-0.009^{* *}$ \\
Own Gain & & & & $(25.67)$ \\
& & & & -0.012 \\
Own Gain X Charter & & & & $(1.61)$
\end{tabular}

Significance: $\sim=10 \% \quad *=5 \% \quad * *=1 \%$

Note: Student characteristics include ethnicity, gender, economic status, migrant status and own mobility indicators; school/peer characteristics include enrollment, grade distribution, and ethnic, disadvantaged and migrant student shares, and percent of student body new; peer achievement is the initial achievement level of the other students in the same grade and school. 
parents are responding to the quality of the school's instructional program rather than the peers. Moreover, inclusion of own gain has virtually no effect on the quality coefficient, providing strong support that the relationship is not driven by omitted factors affecting both performance and the probability of leaving. It is also notable that the coefficients for the student's own achievement gain during the year leading up to the potential exit are also negative and significant (Column 4) and not significantly different for students in charter and traditional public schools.

The magnitude of the coefficients indicates that a one standard deviation increase in school quality reduces the probability of leaving the school by roughly 7 percentage points. ${ }^{28}$ Whatever else parents may be looking for in a charter school, they respond to performance differences in the core academic subjects.

The muted exit response of students in regular public schools almost certainly results in part from the much higher transactions costs typically associated with moving. With fixed attendance zones, parents of students in regular public schools usually have to change residences in order for their child to attend another public school, while children in charter schools can opt back into the regular public schools without having to move. At this time the relatively small number of existing charter schools cannot provide viable alternatives for the large number of regular public school students attending below average schools. Therefore, transactions costs are much higher for most students in regular public schools who desire to change schools.

We can also exploit the added information about the destination of exiting students to learn more about the behavior of regular and charter school students. The three destination categories are "charter school", "regular public school", and "out of the data set". Note that a student can exit from our data entirely by transferring to a private school, moving out of state, or stopping attending schools (largely home schooling), but we have no information to distinguish among these categories. Nevertheless, the "out of the data set" category is included in the model

\footnotetext{
${ }^{28}$ The standard deviation of the school quality distribution is 0.49 for charter schools, although a substantial portion of this variance is measurement error. The error attenuates the coefficient on school quality proportional to its share of the total variance of the school quality residual.
} 
because its share of school exits is not insignificant; Table 4 shows that 18 percent of charter school students and 7 percent of regular public school students disappear from the data each year.

Table 10 reports multinomial logit estimates of the effects of school quality on the probabilities of switching to each of the destinations relative to remaining in the same school. The results suggest that higher quality reduces the probabilities that charter school students return to a traditional public school and exit the data entirely, though the results on exiting the data are not significant at conventional levels. To the extent that a portion of the exits from the data are caused by geographic moves largely unrelated to school quality, it is not surprising that the quality effect would be weaker for this category. Interestingly, the results also suggest a strong relationship between the probability of transitioning from a regular public school to a charter and school quality. It appears that the insignificant estimates for regular public school students in specifications that combine all destinations into a single category result from the fact that most transitions out of regular public schools are not driven by the same quality considerations as the decision to enter a charter school - partly because of a lack of charter school alternatives and partly because most geographic moves are not driven by school quality considerations.

\section{c. Differences by Family Income}

An important question is whether the responsiveness to school quality varies by family income. Table 11 describes the exit regression results from specifications that add interactions between both school quality and own gain and classification as economically disadvantaged. (The coefficients in the multinomial logit specifications were quite imprecise and uninformative, and we do not report these results).

The results suggest that low income families are less responsive to quality than higher income families in both the charter and non-charter school sectors. These estimates suggest that the effect of a one standard deviation reduction in charter school quality on the probability of exiting is roughly half as large for students classified as economically disadvantaged. A number of factors may contribute to this finding including greater mobility for non-school considerations, 
Table 10. Estimated Effects of School Quality on the Probabilities of Exiting Charter and Regular Public Schools, by Destination

(absolute value of $\mathrm{z}$-statistics in parentheses; $\mathrm{n}=1,349,909$ )

Multinomial Logistic Regression

(base alternative = remain in current school)

Student Characteristics

School/Peer Characteristics

Peer Achievement

To Public School
Quality

Quality X Charter

Own Gain

Own Gain X Charter
(1)

YES

NO

NO

$-0.017$

(0.45)

$-0.742 * *$

(4.04)

Quality

Quality X Charter

Own Gain

Own Gain X Charter

Quality

Quality X Charter

Own Gain

0.005

(0.16)

$-0.508^{*}$

(2.27)

0.174

(0.6)

$-0.664^{* *}$

(1.69)

0.047

(1.29)

$-0.727^{* *}$

(3.57)

YES
YES

NO

$(3.57)$
(3)

(4)

$\begin{array}{ll}\text { YES } & \text { YES } \\ \text { YES } & \text { YES } \\ \text { YES } & \text { YES }\end{array}$

0.044

$0.11 * *$

(1.2)

(2.95)

$-0.675^{* *}$

(3.33)

$-0.564 * *$

(2.8)

$-0.065^{* *}$

(20.79)

$0.118^{*}$

(2.44)

$-0.318^{* *}$

(2.66)

0.172

$(0.55)$

$-0.061 *$

$-0.023$

$(0.26)$

$0.115^{* *}$

(3.66)

$-0.678^{* *}$

(2.92)

$-0.114 * *$

(20.73)

$0.283 * *$

Own Gain X Charter

Significance: $\sim=10 \% \quad *=5 \% \quad * *=1 \%$

Note: Student characteristics include ethnicity, gender, economic status, migrant status and own mobility indicators; school/peer characteristics include enrollment, grade distribution, and ethnic, disadvantaged and migrant student shares, and percent of student body new; peer achievement is the initial achievement level of the other students in the same grade and school. 


\section{Table 11. Estimated Effects of School Quality on the Probabilities of Exiting}

Charter and Regular Public Schools by Family Income

(absolute value of $\mathrm{t}$-statistics in parentheses; $\mathrm{n}=1,349,909$ )

\begin{tabular}{|c|c|c|}
\hline & (1) & $(2)$ \\
\hline Quality & $\begin{array}{l}0.000 \\
(0.09)\end{array}$ & $\begin{array}{l}0.008 \\
(1.47)\end{array}$ \\
\hline Quality X Charter & $\begin{array}{c}-0.193 * * \\
(5.18)\end{array}$ & $\begin{array}{c}-0.177^{* *} \\
(4.34)\end{array}$ \\
\hline Quality X Low Income & $\begin{array}{l}0.009 \sim \\
(1.76)\end{array}$ & $\begin{array}{c}0.013^{*} \\
(2.3)\end{array}$ \\
\hline Quality X Low Income X Charter & $\begin{array}{l}0.089 * \\
(2.22)\end{array}$ & $\begin{array}{l}0.08 \sim \\
(1.76)\end{array}$ \\
\hline Own Gain & & $\begin{array}{c}-0.008 * * \\
(17.05)\end{array}$ \\
\hline Own Gain X Charter & & $\begin{array}{c}-0.015 \\
(1.49)\end{array}$ \\
\hline Own Gain X Low Income & & $\begin{array}{c}-0.002 * * \\
(3.4)\end{array}$ \\
\hline Own Gain X Low Income & & 0.007 \\
\hline X Charter & & $(0.46)$ \\
\hline
\end{tabular}

Note: Linear probability models include student and school/peer characteristics including peer achievement. Student characteristics include ethnicity, gender, economic status, migrant status and own mobility indicators; school/peer characteristics include enrollment, grade distribution, and ethnic, disadvantaged and migrant student shares, and percent of student body new; peer achievement is the initial achievement level of the other students in the same grade and school. 
lower quality public school alternatives, less focus on the quality of academic instruction as well as less skill at judging quality for lower income families on average. ${ }^{29}$ Notice that the inverse relationship between the probability of exit and own gain is larger for those classified as economically disadvantaged, consistent with the notion that family shocks that both adversely affect achievement and precipitate school changes are either stronger or more frequent for these students.

\section{Conclusions}

Charter schools have become the primary means to introduce additional choice and competition into the system of publicly supported elementary and secondary education. These schools enjoy enormous popularity as witnessed by the rapid growth of the number of charter schools in many states. Yet, although charter schools may satisfy family preferences regarding various aspects of the education environment, there is little in the way of solid evidence regarding the academic quality of charter schools in comparison to the local public school alternative.

Deducing the effectiveness of charters is difficult, because they exclusively enroll a selfselected group of students. To the extent that factors influencing selection also affect achievement, simple comparisons of scores between charters and regular publics will obviously be very misleading. Texas provides a unique opportunity to gain insight into the quality of charter schools because of both a sizeable number of charter schools and a comprehensive system of collecting data on individual student performance that permits credible analysis.

The results in this paper show that charter schools typically have a rough beginning. Their performance (measured by average value-added in student performance) begins below that of regular public schools during the first year, even after allowing for the selective nature of the student population. But, by the second or third year there are not significant differences in average performance. Of course this start-up phase leads to some uncertainty, as greater numbers

\footnotetext{
${ }^{29}$ In future work we intend to identify geographically defined education markets and explore market dynamics in greater detail.
} 
of students exit charters than comparable regular public schools, and this feeds back to make the start-up even more difficult. Nonetheless, surviving charters perform similarly to regular public schools on average, suggesting that any regulatory judgments should not be made too early.

In terms of the larger implications of introducing additional choice into the school sector, charter school parents appear to respond to quality differences measured in terms of value added to learning in math and reading in deciding whether to remain in the school. Higher quality lowers exit rates in charter schools, though the effect is weaker for lower income families. The comparison of school exit behavior for charters and regular public schools is also informative: the responsiveness to quality in the regular public sector is much smaller than that in the charter sector, but regular school quality does affect the decision to switch to a charter school if available.

The responsiveness of both charter school parents and regular school parents considering charter schools to school quality bodes well for the possibility of an education market that systematically favors higher quality schools. The fact that parents can evaluate the quality of instruction in their own school is important, but a successful education market also requires the families of prospective students to be able to judge the quality of charter schools. At this point we have little direct knowledge about the ability of outsiders to evaluate charter schools, and we hope to investigate this issue in future work using GIS methods to construct local education markets. We do observe only a small, albeit positive correlation between charter school quality and the change in enrollment, suggesting the need to disseminate information more effectively.

These results, which indicate that the average charter school is not overwhelmingly superior to the average regular public school, can be viewed from two very different perspectives on charter school policy. Some have suggested that, if not significantly better in producing achievement gains, they should be eliminated or at least their expansion should be slowed and they should be further regulated. Particular attention is given to the left hand tail of the charter distribution (figure 1) with calls for quick and decisive charter revocation for those at the bottom 
of the distribution. Moreover, low income families appear to act less on quality differences, perhaps because they are either less able to discern quality or less discerning consumers.

The other view is that the calls for eliminating charters come from interested parties and simply reflect the competitive pressures that charters are generating - pressures that should be reinforced and not weakened. Especially given the fact that the poor performers are very disproportionately found in charters in the first years of operation, they should be better supported in their early development so that they can grow to viable schools. Moreover, even disregarding other school outcomes, the negative relationship between the probability of exiting and school quality indicates that parents do place pressure on schools by withdrawing their children in response to poor quality. This quality responsiveness may be reinforced by improving the content of school performance information disseminated, particularly to low income families. Finally, on this side, concerns about poor performers are much more serious with respect to regular public schools, where students without choice alternatives face much more severe problems than a charter school student who can return to the public schools.

Part of these differences simply reflects different philosophical and policy positions that are not much affected by evidence. But part of the differences also reflects current shortcomings in our knowledge: What will the distribution of mature charter schools be? Will parental decision making be sufficient to eliminate poor quality charter (and regular public) schools? Will public schools respond to competitive pressures? These important questions remain unanswered, and even unanswerable given the immaturity of the charter school market today. Understanding the important longer run dynamic outcomes will require patience and a longer period of observation. 
Appendix Table A1. Mean, 25th Percentile, Median and 75th Percentile of Charter School Enrollment in Grades 4-7: 1997-2002

\begin{tabular}{|c|c|c|c|c|c|}
\hline \multirow{2}{*}{\multicolumn{6}{|c|}{ 4th Grade }} \\
\hline & & & & & \\
\hline 10th Percentile & 4 & 6 & 2 & 3 & 3 \\
\hline 25th Percentile & 4 & 6 & 6 & 7 & 8 \\
\hline Median & 8 & 8 & 13 & 14 & 14.5 \\
\hline 75th Percentile & 8 & 19 & 23 & 24 & 23 \\
\hline \multicolumn{6}{|l|}{ 5th Grade } \\
\hline 10th Percentile & 2 & 5 & 4 & 2 & 1 \\
\hline 25th Percentile & 2 & 6 & 6 & 5.5 & 6 \\
\hline Median & 5 & 9 & 12 & 13.5 & 13 \\
\hline 75th Percentile & 8 & 34.5 & 23 & 27 & 26 \\
\hline \multicolumn{6}{|l|}{ 6th Grade } \\
\hline 10th Percentile & 15 & 6 & 4 & 1 & 2 \\
\hline 25th Percentile & 15 & 12 & 6.5 & 3 & 5 \\
\hline Median & 39 & 42.5 & 14 & 13 & 13 \\
\hline 75th Percentile & 50 & 78 & 34.5 & 27 & 29 \\
\hline \multicolumn{6}{|l|}{ 7th Grade } \\
\hline 10th Percentile & 16 & 15 & 5 & 2 & 2 \\
\hline 25th Percentile & 36 & 31 & 6 & 3 & 6 \\
\hline Median & 39 & 42.5 & 17.5 & 10 & 12.5 \\
\hline 75th Percentile & 45 & 61 & 38 & 18.5 & 25.5 \\
\hline
\end{tabular}




\section{References}

Altonji, Joseph G., Todd E. Elder, and Christopher R. Taber. 2005. "Selection on observed adn unobserved variables: Assessing teh effectiveness of Catholic schools." Journal of Political Economy 113,no.1 (February):151-184.

Bifulco, Robert, and Helen F. Ladd. 2004. "The impacts of charter schools on student achievement: Evidence from North Carolina." Terry Sanford Institute of Public Policy, SAN04-01, Duke University (August).

Booker, Kevin, Scott M. Gilpatric, Timothy J. Gronberg, and Dennis W. Jansen. 2004. "Charter school performance in Texas." mimeo, Texas A\&M University (May).

Coleman, James S., Thomas Hoffer, and Sally Kilgore. 1982. High school achievement: public, Catholic and private schools compared. NY: Basic Books.

Evans, William N., and Robert M. Schwab. 1995. "Finishing high school and starting college: Do Catholic schools make a difference?" Quarterly Journal of Economics 110,no.4 (November):941-974.

Finn, Chester E. Jr, Bruno V. Manno, and Gregg Vanourek. 2000. Charter schools in action. Princeton, NJ: Princeton University Press.

Friedman, Milton. 1962. Capitalism and freedom. Chicago: University of Chicago Press.

Grogger, Jeffrey, and Derek Neal. 2000. "Further evidence on the effects of Catholic secondary schooling." In Brookings-Wharton papers on urban affairs, 2000, edited by William G. Gale and Janet Rothenberg Pack. Washington, DC: Brookings Institution Press:151-193.

Gronberg, Timothy J., and Dennis W. Jansen. 2001. Navigating newly chartered waters: An analysis of Texas charter school performance. Austin, TX: Texas Public Policy Foundation.

Hanushek, Eric A., John F. Kain, Daniel M. O'Brien, and Steve G. Rivkin. 2005. "The market for teacher quality." National Bureau of Economic Research, Working Paper No. 11154, (February).

Hanushek, Eric A., John F. Kain, and Steve G. Rivkin. 2002a. "Inferring program effects for specialized populations: Does special education raise achievement for students with disabilities?" Review of Economics and Statistics 84,no.4 (November):584-599.

2002b. "New evidence about Brown v. Board of Education: The Complex Effects of School Racial Composition on Achievement." Working Paper 8741, National Bureau of Economic Research (January).

_ 2004. "Disruption versus Tiebout improvement: The costs and benefits of switching schools." Journal of Public Economics Vol 88/9-10:1721-1746. 
Heckman, James J. 1979. "Sample selection bias as a specification error." Econometrica 47:153161.

Heckman, James J., Robert LaLonde, and Jeffrey Smith. 1999. "The economics and econometrics of active labor market programs." In Handbook of labor economics, edited by Orley Ashenfelter and David Card. Amsterdam: Elsevier Science:1865-2097.

Heckman, James J., and Jeffrey A. Smith. 1999. "The pre-programme earnings dip and the determinants of participation in a social programme: Implications for simple programme evaluation strategies." The Economic Journal 109(July):313-348.

Howell, William G., and Paul E. Peterson. 2002. The education gap: Vouchers and urban schools. Washington, DC: Grookings.

Hoxby, Caroline Minter. 2001. "Changing the profession: How would school choice affect teachers?" Education Matters 1,no.1 (Spring):57-63.

2002. "Would school choice change the teaching profession?" Journal of Human Resources 37,no.4 (Fall):846-891.

2003. "School choice and school productivity (or could school choice be a tide that lifts all boats?)." In The Economics of School Choice, edited by Caroline Minter Hoxby. Chicago: University of Chicago Press.

- 2004. "Achievement in charter schools and regular public schools in the United States: Understanding the differences." (mimeo) (December).

Hoxby, Caroline Minter, and Jonah E. Rockoff. 2004. "The impact of charter schools on student achievement." (mimeo), (November).

Murnane, Richard J., Stuart Newstead, and Randall Olsen. 1985. "Comparing public and private schools: The puzzling role of selectivity bias." Journal of Business and Economic Statistics 3,no.1 (January):23-35.

Nathan, Joe. 1996. Charter schools: Creating hope and opportunity for American education. San Francisco: Jossey-Bass Publishers.

Neal, Derek. 1997. "The effect of Catholic secondary schooling on educational attainment." Journal of Labor Economics 15,no.1, Part 1 (January):98-123.

Nelson, F. Howard, Bella Rosenberg, and Nancy Van Meter. 2004. "Charter school achievement on the 2003 National Assessment of Educational Progress." American Federation of Teachers (August).

Rivkin, Steven G., Eric A. Hanushek, and John F. Kain. 2005. "Teachers, schools, and academic achievement." Econometrica 73,no.2 (March):417-458.

Sander, William. 1996. "Catholic grade schools and academic achievement." Journal of Human Resources 31,no.3 (Summer):540-548.

2001. Catholic schools: Private and social effects. Boston: Kluwer Academic Publishers. 
Sass, Tim R. 2005. "Charter schools and student achievement in Florida." Paper presented at American Economic Association Annual Meetings. Philadelphia.

Texas Center for Educational Research. 2003. Texas open-enrollment charter schools: Sixth year evaluation. Austin, TX: Texas Center for Educational Research (July).

U.S. Department of Education. 1999. State of charter schools third-year report. Washington, DC: U.S. Department of Education. 